\title{
Metabolic Alterations, Vascular Disease and Advanced Prostate Cancer: New Players for Metastatic Advanced Prostate Cancer?
}

\author{
Simona Di Francesco, ${ }^{1, *}$ and Raffaele L. Tenaglia ${ }^{2}$ \\ ${ }^{1}$ Department of Medicine and Aging, University G. D'Annunzio Chieti-Pescara, Italy \\ ${ }^{2}$ Department of Biomedical Sciences, University G. D'Annunzio Chieti-Pescara, Italy
}

\begin{abstract}
Introduction: Epidemiologic studies have implicated metabolic imbalance in prostate cancer (PCa) aggressiveness, nevertheless no clear consensus has been reached. The aim of the research was to investigate the association of hypertension, hypercholesterolemia and vascular disease in advanced PCa with and without bone metastases.

Methods: Retrospective analysis of 66 patients with diagnosis of advanced PCa between 2005 and 2009 was conducted. We examined hypertension, hypercholesterolemia and vascular disease in 25 patients with advanced PCa and bone metastases versus 41 patients with advanced non-metastatic PCa. Men with incomplete data available, history of hormone therapy or chemotherapy, vascular surgery or other anticancer therapies were excluded.

Results: Hypertension was significantly linked to advanced PCa with bone metastases (OR 4.5, $p=0.01$ ). Hypercholesterolemia also was significantly associated with aggressive metastatic $P C a(O R 3.28, p=0.01)$. A significant association was noted between metastatic PCa and vascular disease (OR 3.8, p = 0.04).

Conclusions: In our study, hypertension, hypercholesterolemia and vascular disease were significantly related to advanced metastatic PCa. Further research should elucidate these relations in larger samples to confirm these associations and to stabilize future prevention strategies.
\end{abstract}

Keywords: Prostate Cancer, bone metastases, hypertension, dyslipidaemia, vascular disease.

\section{INTRODUCTION}

Clinical studies have related metabolic imbalance with prostate cancer (PCa) development and aggressiveness with conflicting results [1-12].

Indeed, while the relationship between metabolic alterations as diabetes mellitus (DM), obesity and $\mathrm{PCa}$ has been heavily examined, the influence of factors as hypertension, dyslipidaemia and vascular disease on metastatic PCa has been poorly studied, despite the frequent co-existence of these disorders in prostate cancer [13].

The aim of the research was to evaluate the association of hypertension, dyslipidaemia and vascular disease in advanced metastatic PCa.

\section{METHODS}

Retrospective analysis of 66 patients with diagnosis of advanced $\mathrm{PCa}$ (locally advanced or poorly differentiated cancer; stage T3-4 and/or GS 7-10) between 2005 and 2009 was conducted. We examined arterial hypertension (arterial blood pressure $>130 / 85$ ), dyslipidaemia and vascular disease (carotid vascular disease and/or symptomatic coronary artery disease) in

*Address correspondence to this author at the Department of Medicine and Aging, University G. D'Annunzio Chieti-Pescara, School of Advanced Studies, Italy; Tel: +393334065464; E-mail: docveronica@gmail.com

ISSN: 1927-7210 / E-ISSN: 1927-7229/14
25 patients with advanced $\mathrm{PCa}$ with diagnosed bone metastases (Group 1) versus 41 patients with advanced non-metastatic PCa (Group 2).

We have considered in our study as hypercholesterolemia high levels of Total Cholesterol and LDL-C. Each patient was considered to be the average of at least 3 measurements at the same hospital laboratory at $8 \mathrm{am}$.

Men with incomplete data available, history of hormone therapy or chemotherapy, urological or vascular surgery or other anticancer therapies were excluded.

Differences in the distribution of continuous variables between study groups were described as median or media \pm standard deviation (SD) and assessed for statistical significance with Mann-Whitney Rank Sum Test or t-test. Differences in distributions for categorical variables were expressed as number of patients (frequencies and percentage) and evaluated using Chi-square testing of independence; however, when low cell counts were found, Fisher's exact testing was utilized. A $P$ value $<.05$ was considered statistically significant.

\section{RESULTS}

Cases and controls were age-matched (68 years vs 67 years, respectively, $p=0,423)$. Baseline (c) 2014 Lifescience Global 
Table 1: Baseline Characteristics in Patients with Advanced Non-Metastatic PCa (Group 1) Versus Patients with Advanced Metastatic PCa (Group 2)

\begin{tabular}{|c|c|c|}
\hline & $\begin{array}{c}\text { Group 1 } \\
\text { Advanced Non-Metastatic PCa }\end{array}$ & $\begin{array}{c}\text { Group 2 } \\
\text { Advanced Metastatic PCa }\end{array}$ \\
\hline \hline Age at diagnosis (media \pm SD) & $67 \pm 9.54$ & $68 \pm 6.43$ \\
\hline Systolic Blood Pressure (media \pm SD) & $130 \pm 10.2$ & $140 \pm 9.8$ \\
\hline Diastolic Blood Pressure (media \pm SD) & $80 \pm 4.2$ & $85 \pm 5.4$ \\
\hline LDL-C mg/dl (media \pm SD) & $128 \pm 10.2$ & $149 \pm 12.6$ \\
\hline Total Cholesterol mg/dl (media \pm SD) & $180 \pm 12.8$ & $200 \pm 11.3$ \\
\hline
\end{tabular}

characteristics at initial diagnosis were shown in Table 1.

Hypertension was significantly linked to advanced metastatic $\mathrm{PCa}$ (OR 4.5, $\mathrm{p}=0.01$ ). Hypercholesterolemia, particularly high levels of Total Cholesterol and LDL-C, also was significantly associated with aggressive metastatic PCa (OR 3.28, $p=0.01$ ). A significant association was noted between advanced $\mathrm{PCa}$ with bone metastases and vascular disease (OR $3.8, p=0.04$ ).

\section{DISCUSSION}

More than $30 \%$ of men with $\mathrm{PCa}$ die of cardiovascular disease, which constitutes one of the most common causes of death in this patient population [14-16].

Aggressive PCa spreading to the bone, is a fatal disease requiring early diagnosis and effective treatment [17].

The aim of this study was to examine in a retrospective analysis of 66 patients with diagnosis of advanced $\mathrm{PCa}$ the association between hypertension, hypercholesterolemia and vascular disease with advanced $\mathrm{PCa}$ with bone metastases.

In recent studies hypertension, hypercholesterolemia, atherosclerosis and a composite score of metabolic factors were associated with advanced $\mathrm{PCa}$, biochemical recurrence and an increased risk of death from PCa [5, 18-25].

In our study firstly we found a significant association between arterial hypertension, particularly systolic blood pressure, hypercholesterolemia and vascular disease with advanced PCa with bone metastases.

If confirmed in other larger studies, our results suggested that these alterations could be considered new players in metastatic advanced PCa and suggests common shared etiologies.
A study of Thysel and al. studied metabolites associated with $\mathrm{PCa}$ metastases and particularly identified high levels of cholesterol in $\mathrm{PCa}$ bone metastases. The authors proposed that tumor epithelial cells in PCa bone metastases synthesize cholesterol de novo as well the influx of this metabolite from the surroundings was implicated [17].

The pathogenic mechanisms potentially linking hypertension, hypercholesterolemia and vascular disease to $\mathrm{PCa}$ aggressiveness are complex. The chronic pro inflammatory state and oxidative stress associated with metabolic factors and vascular injury could contribute to progression in advanced metastatic PCa.

The results of the current study also will add some further motivation to control metabolic factors to decrease the risk of cardiovascular disease and $\mathrm{PCa}$ aggressiveness.

\section{CONCLUSIONS}

In our study, hypertension, hypercholesterolemia and vascular disease were significantly related to advanced metastatic PCa.

The metabolic derangements may increase oxidative stress and cause a permanent pro inflammatory state that predisposes to metastatic PCa. Further research should elucidate these relations in larger samples to confirm these associations and to stabilize future prevention strategies.

\section{CONFLICT OF INTEREST STATEMENT}

We have no conflict of interest and no source of funding.

\section{REFERENCES}

[1] Morote J, Celma A, Planas J, Placer J, Konstantinidis C Iztueta I, de Torres IM, Oliván M, Reventós J, Doll A Sedentarism and overweight as risk factors for the detection of prostate cancer and its aggressivenes. Actas Urol Esp 2014 January. 
[2] Su LJ, Arab L, Steck SE, Fontham ET, Schroeder JC, Bensen JT, Mohler JL. Obesity and prostate cancer aggressiveness among African and Caucasian Americans in a population-based study. Cancer Epidemiol Biomarkers Prev 2011; 20: 844-53. http://dx.doi.org/10.1158/1055-9965.EPI-10-0684

[3] Kim HS, Presti JC Jr, Aronson WJ, Terris MK, Kane CJ, Amling CL, Freedland SJ. Glycemic control and prostate cancer progression: results from the SEARCH database. Prostate 2010; 70: 1540-6. http://dx.doi.org/10.1002/pros.21189

[4] Jayachandran J, Aronson WJ, Terris MK, Presti JC Jr, Amling CL, Kane CJ, Freedland SJ. Diabetes and outcomes after radical prostatectomy: are results affected by obesity and race? Results from the shared equal-access regional cancer hospital database. Cancer Epidemiol Biomarkers Prev 2010; 19: 9-17. http://dx.doi.org/10.1158/1055-9965.EPI-09-0777

[5] Häggström $C$, Stocks $T$, Ulmert $D$, Bjørge $T$, Ulmer $H$, Hallmans G, Manjer J, Engeland A, Nagel G, Almqvist M, Selmer R, Concin H, Tretli S, Jonsson H, Stattin P. Prospective study on metabolic factors and risk of prostate cancer. Cancer 2012; 118: 6199-206. http://dx.doi.org/10.1002/cncr.27677

[6] Van Hemelrijck M, Garmo H, Holmberg L, Walldius G, Jungner I, Hammar N, Lambe M. Prostate cancer risk in the Swedish AMORIS study. the interplay among triglycerides, total cholesterol, and glucose. Cancer 2011; 117: 2086-2095. http://dx.doi.org/10.1002/cncr.25758

[7] Shafique K, McLoone P, Qureshi K, Leung H, Hart C, Morrison DS. Cholesterol and the risk of grade-specific prostate cancer incidence: evidence from two large prospective cohort studies with up to 37 years' follow up. BMC Cancer 2012; 12: 25 http://dx.doi.org/10.1186/1471-2407-12-25

[8] Omalu BI, Hammers JL, Parwani AV, Balani J, Shakir A, Ness RB Niger Is there an association between coronary atherosclerosis and carcinoma of the prostate in men aged 50 years and older? An autopsy and coroner based postmortem study. J Clin Pract 2013; 16: 45-8.

[9] Dreyer L, Olsen JH. Risk for non-smoking-related cancer in atherosclerotic patients. Cancer Epidemiol Biomarkers Prev 1999; 8: 915-8.

[10] Stamatiou KN, Alevizos AG, Mihas K, Mariolis AD, Michalodimitrakis E, Sofras F Associations between coronary heart disease, obesity and histological prostate cancer. Int Urol Nephrol 2007; 39: 197-201. http://dx.doi.org/10.1007/s11255-006-9010-z

[11] Heron M, Hoyert DL, Murphy SL, Xu J, Kochanek KD, Tejada-Vera B. Deaths: final data for 2006. Natl Vital Stat Rep 2009; 57: 1-134.

[12] Thomas JA, Gerber L, Bañez LL, Moreira DM, Rittmaster RS, Andriole GL, Freedland SJ. Prostate cancer risk in men with baseline history of coronary artery disease: results from the REDUCE Study. Cancer Epidemiol Biomarkers Prev 2012; 21: $576-81$.

http://dx.doi.org/10.1158/1055-9965.EPI-11-1017

[13] Weaver KE, Foraker RE, Alfano CM, Rowland JH, Arora NK, Bellizzi KM, Hamilton AS, Oakley-Girvan I, Keel G, Aziz NM. Cardiovascular risk factors among long-term survivors of breast, prostate, colorectal, and gynecologic cancers: a gap in survivorship care? J Cancer Surviv 2013; 7: 253-61. http://dx.doi.org/10.1007/s11764-013-0267-9
[14] Satariano WA, Ragland KE, Van Den Eeden SK. Cause of death in men diagnosed with prostate carcinoma. Cancer 1998; 83: 1180-8.

http://dx.doi.org/10.1002/(SICI)1097-

0142(19980915)83:6<1180::AID-CNCR18>3.0.CO;2-1

[15] Fouad MN, Mayo CP, Funkhouser EM, Hall HI, Urban DA, Kiefe $\mathrm{Cl}$. Comorbidity independently predicted death in older prostate cancer patients, more of whom died with than from their disease. J Clin Epidemiol 2004; 57: 721-729. http://dx.doi.org/10.1016/j.jclinepi.2003.11.009

[16] Groome PA, Rohland SL, Siemens DR, Brundage MD, Heaton J, Mackillop WJ. Assessing the impact of comorbid illnesses on death within 10 years in prostate cancer treatment candidates. Cancer 2011; 117: 3943-52. http://dx.doi.org/10.1002/cncr.25984

[17] Thysell E, Surowiec I, Hörnberg E, Crnalic S, Widmark A Johansson Al, Stattin P, Bergh A, Moritz T, Antti H, Wikström $P$. Metabolomic characterization of human prostate cancer bone metastases reveals increased levels of cholesterol. PLoS One 2010; 5: e14175.

http://dx.doi.org/10.1371/journal.pone.0014175

[18] Xu H, Zhang LM, Liu J, Ding GX, Ding Q, Jiang HW. The association between overall survival of prostate cancer patients and hypertension, hyperglycemia, and overweight in Southern China: a prospective cohort study. J Cancer Res Clin Oncol 2013; 139: 943-51.

http://dx.doi.org/10.1007/s00432-013-1407-3

[19] Cheung AS, Pattison D, Bretherton I, Hoermann R, Lim Joon D, Ho E, Jenkins T, Hamilton EJ, Bate K, Chan I, Zajac JD, Grossmann M. Cardiovascular risk and bone loss in men undergoing androgen deprivation therapy for non-metastatic prostate cancer: implementation of standardized management guidelines. Andrology 2013; 1: 583-9. http://dx.doi.org/10.1111/j.2047-2927.2013.00093.x

[20] Asmar R, Beebe-Dimmer JL, Korgavkar K, Keele GR, Cooney KA Hypertension, obesity and prostate cancer biochemical recurrence after radical prostatectomy. Prostate Cancer Prostatic Dis 2013; 16: 62-6.

http://dx.doi.org/10.1038/pcan.2012.32

[21] Sternberg CN, Baskin-Bey ES, Watson M, Worsfold A, Rider A, Tombal B. Treatment patterns and characteristics of European patients with castration-resistant prostate cancer. BMC Urol 2013; 13: 58. http://dx.doi.org/10.1186/1471-2490-13-58

[22] Esposito K, Chiodini P, Capuano A, Bellastella G, Maiorino MI, Parretta E, Lenzi A, Giugliano D. Effect of metabolic syndrome and its components on prostate cancer risk: metaanalysis. J Endocrinol Invest 2013; 36: 132-9.

[23] Kurata S, Tateishi U, Shizukuishi K, Yoneyama T, Hino A, Kaida $\mathrm{H}$, Fujimoto $\mathrm{K}$, Ishibashi M, Inoue T. Assessment of atherosclerosis in oncologic patients using ${ }^{18} \mathrm{~F}$-fluoride PET/CT. Ann Nucl Med 2013; 27: 481-6. http://dx.doi.org/10.1007/s12149-013-0706-8

[24] Lee BH, Taylor MG, Robinet P, Smith JD, Schweitzer J, Sehayek E, Falzarano SM, Magi-Galluzzi C, Klein EA, Ting $\mathrm{AH}$. Dysregulation of cholesterol homeostasis in human prostate cancer through loss of ABCA1. Cancer Res 2013; 733: $1211-8$.

http://dx.doi.org/10.1158/0008-5472.CAN-12-3128

[25] Shafique K, McLoone P, Qureshi K, Leung H, Hart C, Morrison DS Cholesterol and the risk of grade-specific prostate cancer incidence: evidence from two large prospective cohort studies with up to 37 years' follow up. BMC Cancer 2012; 12: 25.

http://dx.doi.org/10.1186/1471-2407-12-25 